\title{
Purpuric lesions: what diagnosis?
}

\author{
Catarina Neves, ${ }^{1}$ Nádia Brito, ${ }^{2}$ Dulce Santos, ${ }^{2}$ Lourdes Mota ${ }^{2}$
}

${ }^{1}$ Hospital Pediátrico de Coimbra, Centro Hospitalar e Universitário de Coimbra, EPE, Coimbra, Portugal ${ }^{2}$ Hospital Distrital da Figueira do Foz, EPE, Figueira da Foz, Portugal

\section{Correspondence to}

Dr Catarina Neves,

catarinarneves@hotmail.com

Accepted 10 February 2016

\section{DESCRIPTION}

A previously healthy 9-month-old baby was admitted to the emergency department, with a sudden onset of non-itching rash without fever. He had displayed flu-like symptoms the previous week. There was no recent ingestion of drugs and no recent vaccinations.

At admission, he was afebrile, with excellent overall health, heart rate $106 \mathrm{bpm}$, blood pressure $87 / 39 \mathrm{~mm} \mathrm{Hg}$, capillary refill time <2". On skin examination, he had multiple annular purpuric lesions in the lower limbs and non-pitting oedema of the feet (figure 1). The blood count, coagulation profile, $\mathrm{C}$ reactive protein, renal function and urinary dipstick were normal. Furthermore, blood and urine cultures were negative. The symptoms resolved completely in 2 weeks, with symptomatic treatment. The clinical diagnosis of acute haemorrhagic oedema of infancy was established.

This is an uncommon disease (there are about 300 cases reported), which typically occurs in children $<2$ years. The aetiology remains unknown and the onset is sudden. It is an antineutrophil cytoplasmic antibody-negative leucocytoclastic vascu-

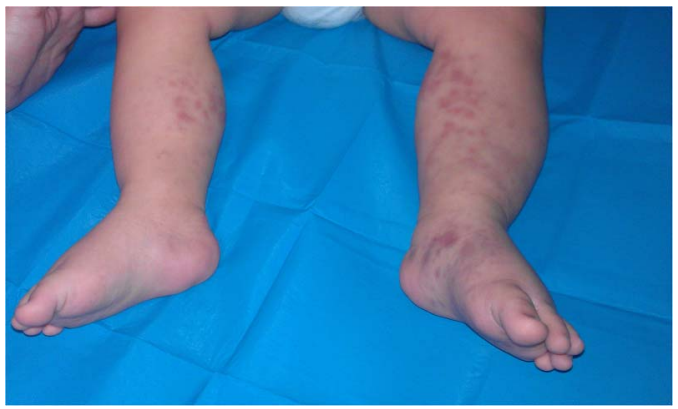

Figure 1 Purpuric lesions with well-defined edges and central vascular drawings and oedema, located on the legs and feet, are seen. litis, characterised histologically by inflammation of the small dermal vessels, with fibrinoid necrosis and extravasation of red blood cells, and clinically by large, annular, purpuric lesions predominantly over the face, ears and extremities, often with nonpitting oedema of the extremities, ears and face. The exuberance of the lesions contrasts with a wellappearing child and with the benign course of the disease, which resolves spontaneously in 1-3 weeks. The differential diagnosis includes meningococcemia, erythaema multiforme, haemorrhagic urticaria, drug eruption and child abuse. Whether or not this disease is a mild variant of Hennoch-Scönlein purpura remains controversial. ${ }^{1-3}$

\section{Learning points}

Acute haemorrhagic oedema of infancy typically occurs in the first 2 years of life.

- The exuberance of skin lesions contrasts with a well-appearing child and with the benign course of the disease.

- The clinical diagnosis of this entity may avoid elaborate or invasive investigations.

\section{Competing interests None declared.}

Patient consent Obtained.

Provenance and peer review Not commissioned; externally pee reviewed.

\section{REFERENCES}

1 Carvalho C, Januário G, Maia P. Acute haemorrhagic oedema of infancy. BMJ Case Rep 2013;2013:pii: bcr2012008145.

2 Fiore E, Rizzi M, Simonetti GD, et al. Acute hemorrhagic edema of young children: a concise narrative review. Eur J Pediatr 2011:170:1507-11.

3 Ferrarini A, Benetti C, Camozzi P, et al. Acute hemorrhagic edema of young children: a prospective case series. Eur J Pediatr 2015. Published Online First.

Copyright 2016 BMJ Publishing Group. All rights reserved. For permission to reuse any of this content visit

http://group.bmj.com/group/rights-licensing/permissions.

BMJ Case Report Fellows may re-use this article for personal use and teaching without any further permission.

Become a Fellow of BMJ Case Reports today and you can:

- Submit as many cases as you like

- Enjoy fast sympathetic peer review and rapid publication of accepted articles

- Access all the published articles

- Re-use any of the published material for personal use and teaching without further permission

For information on Institutional Fellowships contact consortiasales@bmjgroup.com

Visit casereports.bmj.com for more articles like this and to become a Fellow 